\title{
Substantiation of the parameters of a typical seed-growing farms of the republic of kazakhstan on the basis of digitalization of seed production
}

\author{
A.S. Alchimbayeva ${ }^{1,2}$, Lyudmila Shibryaeva ${ }^{1,3}$, Zharylkasyn Sadykov ${ }^{2}$, \\ Mikhail Chaplygin ${ }^{1, *}$, and Rizvankoul Kaimova ${ }^{2}$ \\ ${ }^{1}$ Federal Research Agro-Engineering Center VIM, 1st Institutskiy proezd, 5, Moscow, 109428, Russia \\ ${ }^{2}$ Astrakhan State University,st. Tatishcheva, 20A, Astrakhan, 414056, Russia \\ ${ }^{3}$ N. M. Emanuel Institute of Biochemical Physics, Russian Academy Sciences, \\ 119334, Kosygina str., 4, Moscow, Russia
}

\begin{abstract}
In general, the state of seed production in Kazakhstan can be characterized by the following figures. According to Kostanay branch of Kazakh research Institute of mechanization and electrification of agriculture total requirement of seeds is around 2 million tons. These farms provide $70 \%$ of the Republic's farms with seeds, the remaining $30 \%$ are imported from Russia. The studies have shown that all grain-producing regions of Kazakhstan can be classified into three categories according to the annual gross grain harvest, respectively, $16 ; 15 ; 3.26$ and 2.9 million tons. It is advisable that typical seed farms have the following characteristics: in the first category of regions - the average area of one farm -2.8 thousand hectares, the average annual grain harvest -8.06 thousand tons, agro term -10 days, the required total seed collection -1.78 million tons for all seed farms in the amount of 220 units. Accordingly, in the second category of regions - 1100 hectares; 2.82 thousand tons; 9.5 days 360 thousand tons and 128 units. In a third category -322 hectares of 1.02 million tons, or 9.1 days, 320 thousand tons and 312 units. Total number of typical specialized farms should be approximately 660 units.
\end{abstract}

\section{Introduction}

The analysis of the reproductive composition of the sown crops for the harvest of 20132017 shows ( $\%$ ) that the share of crops sown with elite seeds increased from $3.5 \%$ in 2016 to $5.2 \%$ in 2017 , the use of IV-V seeds and mass reproduction decreased from $20.5 \%$ to $12.8 \%$; according to scientific data, the lost volume from the use in the production of lowproductive seeds reaches $20 \%$. In 2016, 5 million tons were lost, in $2017-4.7$ million tons, over the past 5 years - 23 million tons; in the EU, USA, Canada only high reproduction

\footnotetext{
* Corresponding author: zhalnin@yandex.ru
} 
seeds are used - elite and 1 reproduction; in the CIS countries (Russian Federation, Republic of Belarus) seeds are used not lower than the 3rd reproduction.

The data of technical equipment of seed producers shows that: the provision of seed farms with sowing equipment is on average $70 \%$, harvesting $-80 \%$, seed cleaning $-63 \%$; of the total availability of equipment, $24 \%$ of sowing, $12 \%$ of harvesting and $25 \%$ of seed cleaning equipment is subject to write-off; the highest percentage of wear of equipment is noted in the originators; the use of seed farms of worn equipment entails an overrun of fuel and electricity in the amount of 1.1 billion tenge per year. In addition, the worn seed cleaning technique increases the injury rate of seeds by $4-10 \%$ depending on the type of culture, reduces germination by $6-15 \%$, the yield of conditioned seeds - up to $10 \%$, and the productivity of seed yield (tons/hour) up to $50 \%$ [1].

The need to determine the parameters of seed farms is caused by two circumstances. The first is that the existing seed farms in the Republic of Kazakhstan were created almost spontaneously during the period of agrarian reforms in 1991-2000. They are not proportionally located on the territory of the country, they are not structured by area, quantity in the region, the required volumes of production of seeds of high standards in compliance with the terms of variety renewal. The second circumstance is caused by the modern national agrarian policy on providing farms with seeds of own production and use of foreign seeds only as improvers of sowing qualities of own grades of grain crops. Currently, the need for seeds in the country up to $30 \%$ depends on the Russian import of seeds. The varietal composition of the sown seeds of agricultural crops for the harvest of 2017 shows a high share of use in the production of foreign selection varieties: oats $57.2 \%$, rice $-76 \%$, flax $-63.3 \%$, mustard $-74.6 \%$, ginger $-78 \%$, rape $-44 \%$, for all legumes $-93.7 \%$, annual herbs $-69.2 \%$, sugar beet $-98 \%$ [1].

The aim of research. To justify the parameters of typical seed farms on the basis of statistical data on indicators of grain production in 12 grain-producing regions of Kazakhstan and other information sources in the regions.

\section{Experimental}

Research methods included statistical processing of initial data on grain production by regions in the Republic of Kazakhstan [2], classification of regions by gross grain production into three categories, identification of typical seed farms and their production characteristics. The calculations were performed according to the known formulas $[3,4]$.

\section{Results and discussion}

In accordance with the guidelines [5,6,7] for each region of Kazakhstan, the dynamics of indicators by area $(\mathrm{S})$, yield $\left(\mathrm{Y}_{\mathrm{s}}\right)$ and gross grain harvest $(\mathrm{Ws})$ for the last three years was analyzed. This gave the possibility to check the production of grain in Kazakhstan on the stability in key parameters. The statistical sample is presented in table 1.

According to table. 1 histograms are built (Figure 1-3). The analysis of histograms showed that in general in Kazakhstan over the past three years there is a fairly stable stability of the overall indicators of grain production. Fluctuations in area do not exceed $-2 \%$, yield $-6 \%$, gross grain harvest $-6 \%$. This makes it possible to further focus on the performance of grain production in 2018 , as more updated. 
Table 1. Statistical sample according to the Statistical office of Kazakhstan.

\begin{tabular}{|c|c|c|c|c|c|c|c|c|c|c|}
\hline \multirow{2}{*}{$\begin{array}{l}\text { Name of } \\
\text { area }\end{array}$} & \multicolumn{3}{|c|}{ Area, S-thousand hectares } & \multicolumn{3}{|c|}{$\begin{array}{l}\text { Yield, Ys - centner / } \\
\text { hectare }\end{array}$} & \multicolumn{3}{|c|}{$\begin{array}{l}\text { Grain harvest Ws, thousand } \\
\text { tons }\end{array}$} & \multirow{2}{*}{\begin{tabular}{|l|} 
Duratio \\
n of \\
harvest \\
ing \\
Tharve \\
st \\
10 \\
\end{tabular}} \\
\hline & 2016 & 2017 & 2018 & 2016 & 2017 & 2018 & 2016 & 2017 & 2018 & \\
\hline Akmola & 4328,7 & 4353,8 & 4320,7 & 13,2 & 11,8 & 13,0 & 5701,3 & 5123,9 & 5611,5 & 10 \\
\hline Aktobe & 340,9 & 389,8 & 441,7 & 13,0 & 13,2 & 11,7 & 443,0 & 512,8 & 514,0 & 7 \\
\hline Almaty & 455,2 & 449,6 & 450,2 & 28,1 & 29,3 & 30,0 & 1268,7 & 1298,5 & 1339,3 & 10 \\
\hline \begin{tabular}{|l|} 
East \\
Kazakhstan \\
\end{tabular} & 573,4 & 566,6 & 539,9 & 18,1 & 13,8 & 14,9 & 1037,7 & 779,1 & 802,5 & 10 \\
\hline \begin{tabular}{|l|} 
West \\
Kazakhstan \\
\end{tabular} & 215,3 & 235,4 & 275,8 & 14,8 & 15,1 & 6,7 & 317,7 & 368,5 & 163,5 & 7 \\
\hline Zhambyl & 266,3 & 274,8 & 300,7 & 25,7 & 24,5 & 26,5 & 683,4 & 672,3 & 791,7 & 10 \\
\hline Karaganda & 741,3 & 794,7 & 833,5 & 14,0 & 10,5 & 12,6 & 1013,5 & 817,7 & 1024,8 & 10 \\
\hline Kostanay & 4215,0 & 4192,8 & 4060,3 & 13,3 & 12,5 & 12,8 & 5613,6 & 5225,3 & 5214,0 & 10 \\
\hline Pavlodar & 673,9 & 710,0 & 725,6 & 12,1 & 10,7 & 12,4 & 817,4 & 754,4 & 900,5 & 10 \\
\hline \begin{tabular}{|l|} 
North \\
Kazakhstan \\
\end{tabular} & 3217,7 & 3087,5 & 2801,0 & 17,6 & 18,2 & 19,0 & 5663,2 & 5627,5 & 5323,1 & 7 \\
\hline Turkistan & 260,4 & 258,9 & 277,9 & 25,7 & 22,3 & 23,0 & 670,2 & 577,8 & 635,5 & 10 \\
\hline $\begin{array}{l}\text { Total by } \\
\text { country }\end{array}$ & $\sum_{=15288} \mathrm{~S}$ & $\sum_{1 \mid=1531} S$ & \begin{tabular}{|l|l|} 
& $\mathrm{S}$ \\
9 & $\mathrm{~S}$ \\
$=15035$
\end{tabular} & \begin{tabular}{|l|l}
$\sum \mathrm{y}$ \\
$=15,2$
\end{tabular} & \begin{tabular}{|l|l}
$\mid \sum \mathrm{y}$ \\
$=14,2$
\end{tabular} & $\begin{array}{l}\sum \mathrm{Y}= \\
14,8\end{array}$ & $\sum_{=233} \mathrm{~W}_{3}$ & $\begin{array}{l}\sum \mathrm{W}_{3} \\
7=2175 \\
\end{array}$ & $8 \sum_{=22320}$ & $\mathrm{~T}=9$ \\
\hline
\end{tabular}

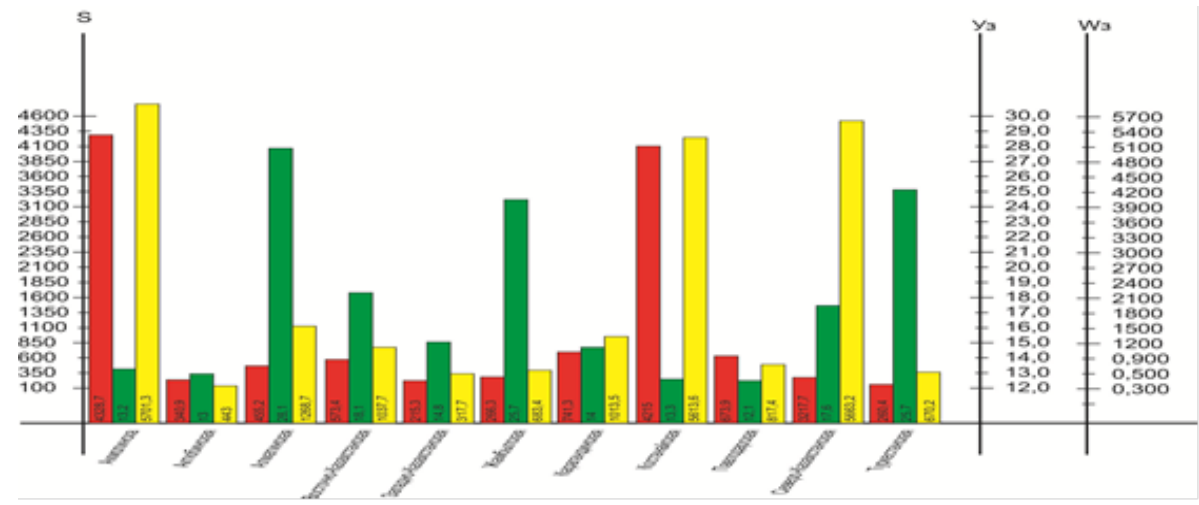

Fig. 1. Histogram of distribution of grain production indicators by regions in the Republic of Kazakhstan (according to the statistical office of the Ministry of agriculture of Kazakhstan) 2016. 


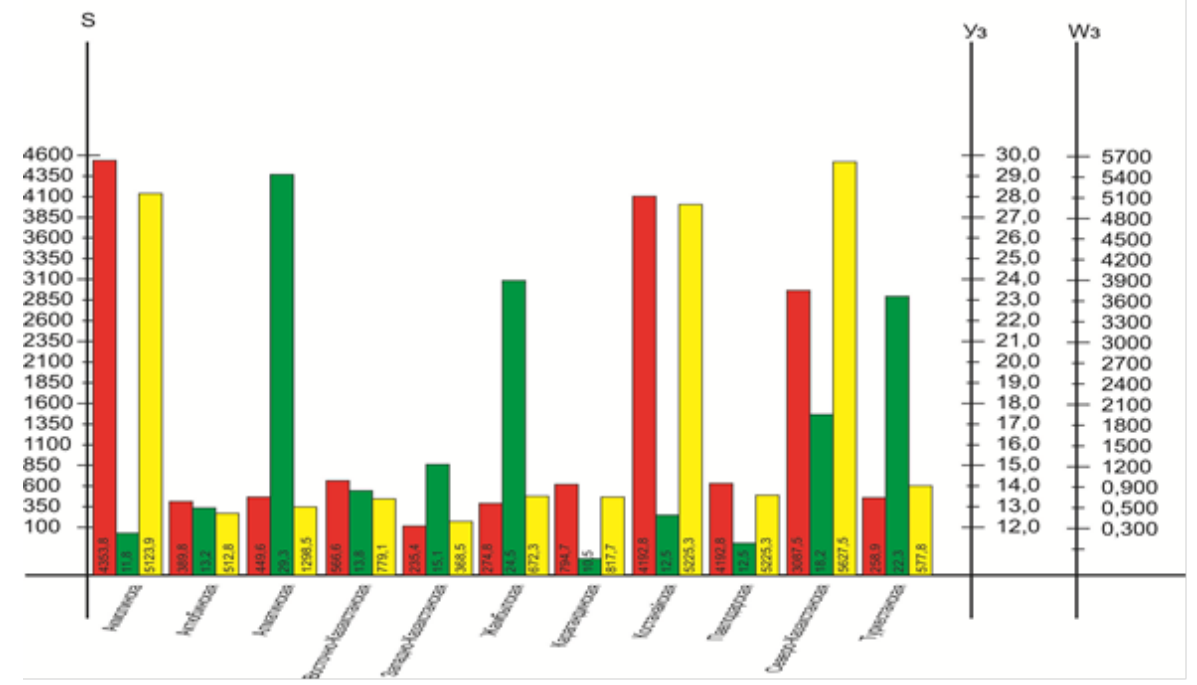

Fig. 2. Histogram of distribution of grain production indicators by regions in the Republic of Kazakhstan (according to the statistical office of the Ministry of agriculture of Kazakhstan) 2017.

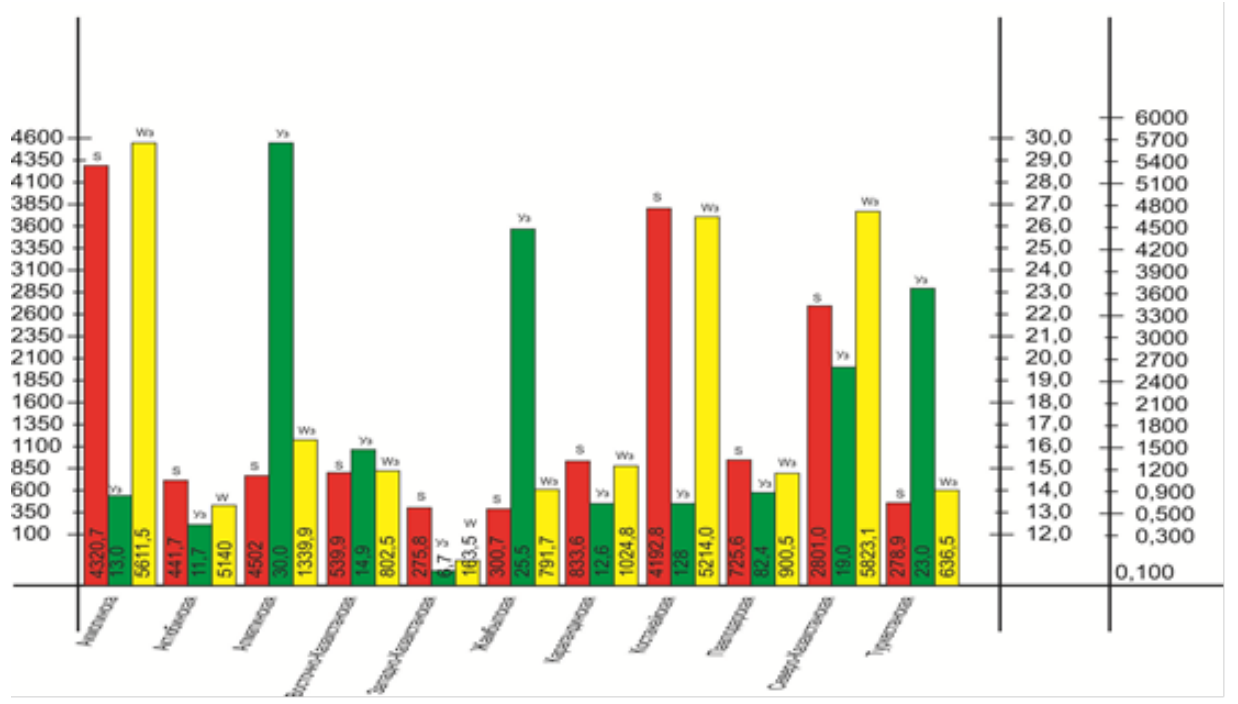

Fig. 3. Histogram of distribution of grain production indicators by regions in the Republic of Kazakhstan (according to the statistical office of the Ministry of agriculture of Kazakhstan) 2018.

All regions of Kazakhstan on grain production can be classified into three categories (I, II, III) (Table 2). The first category of regions includes three regions: Akmola, Kostanay, North Kazakhstan with a total area of 11.182 million hectares, an average yield of $1.44 \mathrm{t} /$ ha, total gross grain harvest of 16.10 million tons. The second category of regions includes: Almaty, Karaganda, Pavlodar with a total area of 2.00 million hectares, an average yield of $1.83 \mathrm{t} / \mathrm{ha}$ and a gross grain harvest of 3.66 million tons. 
The third category of farms includes five regions: Aktobe, Western Kazakhstan, Turkestan, East Kazakhstan, Zhambyl with a total area of 1.84 million hectares, an average yield of $1.60 \mathrm{t} / \mathrm{ha}$ and a gross grain harvest of 2.94 million tons.

In the distribution of regions by categories, it was found that the dynamics of grain production in Kazakhstan by region also varies little over the years (table. 2). For example, for the largest grain-producing regions of the I category, the area under grain has changed by only $4 \%$, the yield has not changed, and the total volume of grain production by $5 \%$, that is, within the error of statistical data. This once again confirms the feasibility of further use of the 2018 data.

Table 2. Distribution of regions of the Republic of Kazakhstan by categories depending on the volume of grain production

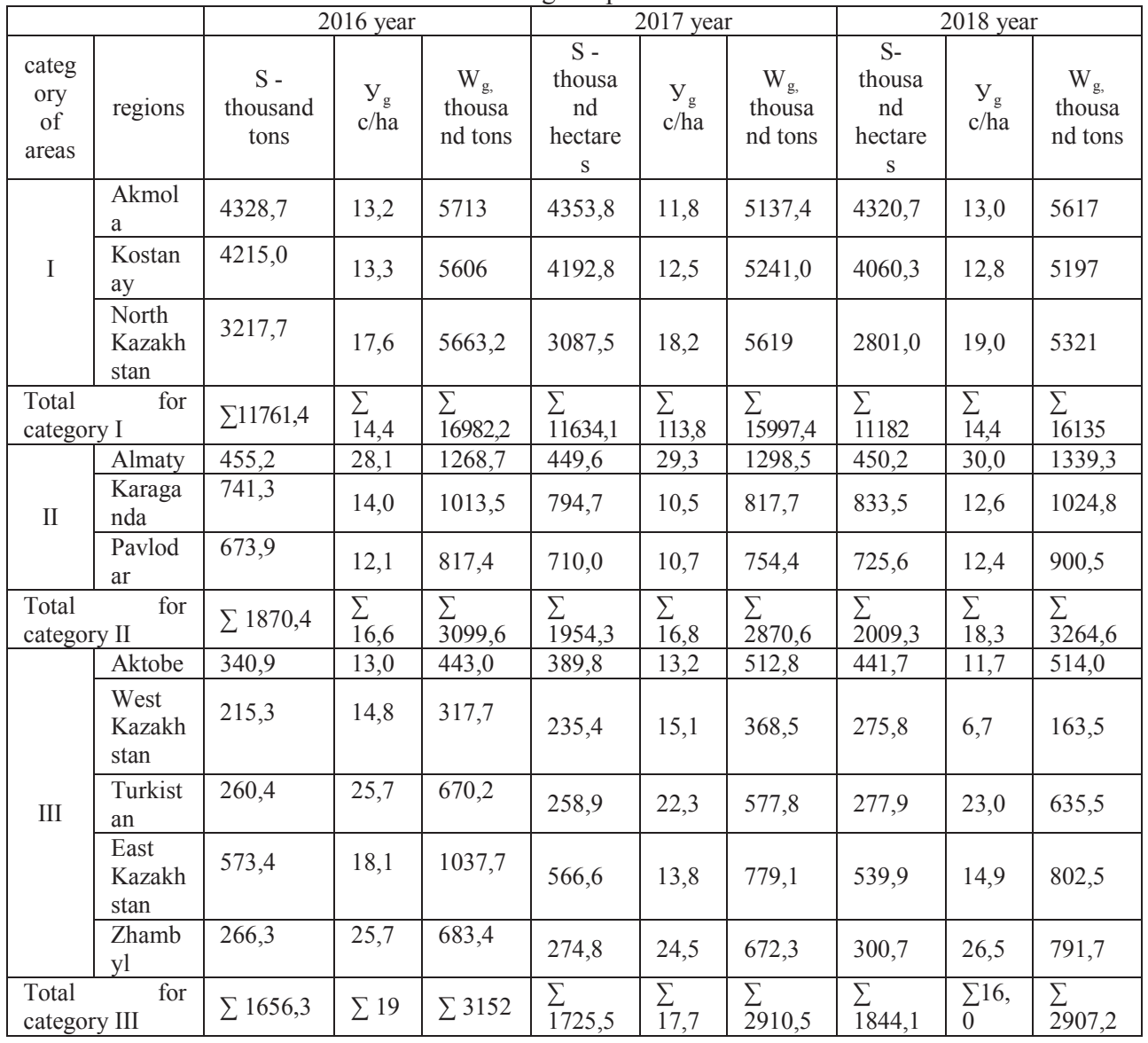

Taking into account the revealed variability of data for each region, each category of farms was characterized by the weighted average value of each parameter (table 3 ). 
Table 3. Results of calculations of weighted average parameters of grain production by categories of regions (2018)

\begin{tabular}{|c|c|c|c|c|c|c|c|c|}
\hline \multicolumn{2}{|c|}{$\begin{array}{l}\text { Groups of areas } \\
\text { in each } \\
\text { Categories }\end{array}$} & \multirow[t]{2}{*}{$\begin{array}{l}\mathrm{S}- \\
\text { thousand } \\
\text { hectares } \\
\text { and } \\
\text { frequenc } \\
\mathrm{y} \\
\mathrm{a}_{\mathrm{i}} \\
4320,7 ; \\
0,39\end{array}$} & \multirow{2}{*}{$\begin{array}{l}\mathrm{y}_{\mathrm{g}} \mathrm{c} / \mathrm{ha} \\
\text { taking } \\
\text { into } \\
\text { account } \\
\mathrm{a}_{\mathrm{i}} \\
13,0\end{array}$} & \multirow{2}{*}{$\begin{array}{l}\mathrm{W}_{\mathrm{g}} \\
\text { thousand } \\
\text { tons } \\
\text { taking into } \\
\text { account } \\
\mathrm{a}_{\mathrm{i}} \\
5617\end{array}$} & \multirow[t]{2}{*}{$\begin{array}{l}\text { Dura } \\
\text { tion } \\
\text { of } \\
\text { harv } \\
\text { estin } \\
\mathrm{g} \\
\mathrm{T}_{\text {harv }} \\
\text { days } \\
10\end{array}$} & \multirow{2}{*}{$\begin{array}{l}\text { Number } \\
\text { of farms } \\
\text { in the } \\
\text { region } \\
\mathrm{Nx} \\
\text { consideri } \\
\mathrm{ng} \mathrm{a}_{\mathrm{i}} \\
1801\end{array}$} & \multirow{2}{*}{$\begin{array}{l}\begin{array}{l}\text { Average } \\
\text { area of } \\
\text { one farm } \\
\mathrm{S} / \mathrm{N}_{\mathrm{x}}, \\
\text { thousand } \\
\text { hectares }\end{array} \\
2,4\end{array}$} & \multirow[t]{2}{*}{$\begin{array}{l}\text { The } \\
\text { average } \\
\text { yield of } \\
\text { grain } \\
\mathrm{W}_{\mathrm{g}} / \mathrm{N}_{\mathrm{x}} \\
\text { thousand / } \mathrm{t} \\
\text { on one } \\
\text { house. } \\
3,12\end{array}$} \\
\hline \multirow{4}{*}{ I } & Akmola & & & & & & & \\
\hline & $\begin{array}{l}\text { Kostana } \\
\text { y }\end{array}$ & $\begin{array}{l}4060,3 ; \\
0,36\end{array}$ & 12,8 & 5197 & 10 & 955 & 4,25 & 5,45 \\
\hline & $\begin{array}{l}\text { North } \\
\text { Kazakhs } \\
\text { tan }\end{array}$ & $\begin{array}{l}2801,0 ; \\
0,25\end{array}$ & 19,0 & 5322,1 & 10 & 1298 & 2,16 & 4,10 \\
\hline & $\begin{array}{l}\text { Weighte } \\
\mathrm{d} \\
\text { average }\end{array}$ & $\mathrm{S}=3847$ & $y=14,4$ & $\mathrm{~W},=5391$ & 10 & $\mathrm{~N}=1370$ & $\mathrm{~S}=2,8$ & $\mathrm{~W}=4,03$ \\
\hline \multirow{4}{*}{ II } & Almaty & $\begin{array}{l}450,2 ; 0,2 \\
2\end{array}$ & 30,0 & 1350,6 & 7 & 1869 & 0,21 & 0,71 \\
\hline & $\begin{array}{l}\text { Karagan } \\
\text { da }\end{array}$ & $\begin{array}{l}833,5 ; \\
0,41\end{array}$ & 12,6 & 1050,2 & 10 & 663 & 1,26 & 1,54 \\
\hline & $\begin{array}{l}\text { Pavloda } \\
\mathrm{r}\end{array}$ & $\begin{array}{l}725,6 \\
0,36\end{array}$ & 12,4 & 900,5 & 10 & 517 & 1,40 & 1,74 \\
\hline & $\begin{array}{l}\text { Weighte } \\
\mathrm{d} \\
\text { average }\end{array}$ & $\mathrm{S}=701$ & $\mathrm{y}=16,2$ & $\mathrm{~W}=1610$ & 9,5 & $\mathrm{~N}=870$ & $\mathrm{~S}=1,1$ & $\mathrm{~W}=1,41$ \\
\hline \multirow{6}{*}{ III } & Aktobe & $\begin{array}{l}441,7 ; 0,2 \\
4\end{array}$ & 11,7 & 514,0 & 10 & 594 & 0,74 & 0,86 \\
\hline & $\begin{array}{l}\text { West } \\
\text { Kazakhs } \\
\text { tan }\end{array}$ & $\begin{array}{l}275,8 ; 0,1 \\
5\end{array}$ & 6,7 & 163,5 & 10 & 559 & 0,49 & 0,29 \\
\hline & $\begin{array}{l}\text { Turkista } \\
\mathrm{n}\end{array}$ & $\begin{array}{l}277,9 ; 0,1 \\
5\end{array}$ & 23,0 & 635,5 & 7 & 3650 & 0,07 & 0,17 \\
\hline & $\begin{array}{l}\text { East } \\
\text { Kazakhs } \\
\text { tan }\end{array}$ & $\begin{array}{l}539,9 ; 0,2 \\
9\end{array}$ & 14,9 & 802,5 & 10 & 1158 & 0,46 & 0,69 \\
\hline & $\begin{array}{l}\text { Zhamby } \\
1\end{array}$ & $\begin{array}{l}300,7 \\
0,16\end{array}$ & 26,5 & 791,7 & 7 & 708 & 0,42 & 1,11 \\
\hline & $\begin{array}{l}\text { Weighte } \\
\mathrm{d} \\
\text { average }\end{array}$ & $S=394$ & $\mathrm{y}=15,8$ & $\mathrm{~W}=622,5$ & 9,1 & $\mathrm{~N}=1224$ & $\mathrm{~S}=0,322$ & $\mathrm{~W}=0,51$ \\
\hline
\end{tabular}

As a result, the parameters of typical seed farms with a certain grain harvest obtained. According to protocols of machine testing stations and reference data other approximate parameters of the typical categories of areas are determined: duration of the grain harvest (agrotechnical permissible period), shoulder the transportation of grain on the route " barnyard " and back, operating speed of traffic, etc. These data are shown in table 4.

The analysis of the table shows that the largest area under grain crops in Kazakhstan is in Akmola region - 4.32 million hectares with a yield of $13 \mathrm{~kg} / \mathrm{ha}$, and the smallest area in West Kazakhstan - 276 thousand hectares with a yield of $6.7 \mathrm{~kg} / \mathrm{ha}$. The highest yield in Almaty region is $30 \mathrm{~kg} / \mathrm{ha}$.

The weighted average area under grain crops in one farm of the first category is 2.8 thousand hectares, the second 1100 hectares and the third 322 hectares, respectively, with an average gross grain harvest of 4.0 thousand tons, 1,4 and 0.51 thousand tons. This distribution of grain production indicators is largely due to the presence in the regions of the second and third categories of a large number of small farms, farmers, private 
enterprises, etc. For example, if in large areas of the first and second categories there are about 7100 all grain farms, in the III category there are almost 6670 farms.

Table 4 summarizes the operating conditions of combine harvesters in the three categories. These data are taken as the basic characteristics of a typical seed-growing farms.

Table 4. Summary of weighted average technical data-operational indicators of harvesting by categories of areas (2018 parameters of typical farms in the region)

\begin{tabular}{|c|c|c|c|c|c|c|c|c|c|c|c|c|}
\hline \multirow[t]{3}{*}{$\begin{array}{l}\text { Ar } \\
\text { ea } \\
\text { cat } \\
\text { eg } \\
\text { or } \\
y\end{array}$} & \multirow{3}{*}{$\begin{array}{l}\text { Averag } \\
\text { e area } \\
\mathrm{S}_{\mathrm{y} \sigma}- \\
\text { million } \\
\text { hectares } \\
\text { across } \\
\text { areas } \\
\text { (table.3 } \\
\text { ) }\end{array}$} & \multirow[t]{3}{*}{$\begin{array}{l}\mathrm{y}_{3} \\
\mathrm{t} / \mathrm{ha} \\
\text { grain } \\
\text { yield }\end{array}$} & \multirow{3}{*}{$\begin{array}{l}\mathrm{W}_{3} \\
\text { milli } \\
\text { on } \\
\text { tons } \\
\text { the } \\
\text { gross } \\
\text { grain } \\
\text { harv } \\
\text { est } \\
\text { mil..t }\end{array}$} & \multirow{3}{*}{$\begin{array}{l}\text { Nx } \\
\text { Total } \\
\text { num } \\
\text { ber } \\
\text { of } \\
\text { farm } \\
\mathrm{s} \text { in } \\
\text { the } \\
\text { regio } \\
\text { ns }\end{array}$} & \multirow{3}{*}{$\begin{array}{l}\mathrm{S}_{\text {harv }} \\
\text { Averag } \\
\text { e area } \\
\text { of one } \\
\text { farm } \\
\text { Sy } \sigma=\sum \\
\mathrm{S} / \mathrm{N}_{\mathrm{x}}, \\
\text { thousa } \\
\text { nd } \\
\text { hectare } \\
\mathrm{s}\end{array}$} & \multicolumn{2}{|c|}{$\begin{array}{l}\mathrm{W}_{3} \text { The average } \\
\text { yield of grain on } \\
\text { one farm } \\
\mathrm{W}_{3}=\mathrm{W}_{3} / \mathrm{N}_{\mathrm{x}} \\
\text { thousand tons }\end{array}$} & \multirow{3}{*}{$\begin{array}{l}\text { Dura } \\
\text { tion } \\
\text { of } \\
\text { harv } \\
\text { estin } \\
\mathrm{g} \\
\mathrm{T}_{\text {harve }} \\
\text { sting }\end{array}$} & \multirow{2}{*}{\multicolumn{2}{|c|}{$\begin{array}{l}\text { Distance of } \\
\text { grain } \\
\text { transportation } \\
\text { from the field } \\
\mathrm{L}, \mathrm{km}\end{array}$}} & \multicolumn{2}{|c|}{$\begin{array}{l}\text { Speed of } \\
\text { transport } \\
\text { ation }\end{array}$} \\
\hline & & & & & & \multirow[b]{2}{*}{$\begin{array}{l}\text { Typi } \\
\text { cal } \\
\text { farm } \\
\text { with } \\
\text { food } \\
\text { and } \\
\text { feed } \\
\text { grain }\end{array}$} & \multirow[b]{2}{*}{$\begin{array}{l}\text { The } \\
\text { typical } \\
\text { seed farm } \\
\text { with the } \\
\text { productio } \\
\mathrm{n} \text { of seed } \\
\text { grain }\end{array}$} & & & & \multirow{2}{*}{$\begin{array}{l}\text { bar } \\
\text { ny } \\
\text { ard }\end{array}$} & \multirow{2}{*}{$\begin{array}{l}\mathrm{Ba} \\
\mathrm{rn} \\
\text { yar } \\
\mathrm{d}\end{array}$} \\
\hline & & & & & & & & & there & back & & \\
\hline I & $3, .85$ & 1.44 & 5.44 & 1370 & 2,800 & 4,03 & 8,06 & 10 & 20 & 18 & 50 & 55 \\
\hline II & 0.7 & 1.62 & 1,13 & 870 & 1,1 & 1,41 & 2,82 & 9.5 & 15 & 12 & 45 & 50 \\
\hline III & $\begin{array}{l}0,39 \\
4\end{array}$ & 1,58 & $\begin{array}{l}0,62 \\
3\end{array}$ & 1224 & 0,322 & 0,51 & 1,02 & 9,1 & 10 & 10 & 40 & 45 \\
\hline
\end{tabular}

At the same time, it is taken into account that according to long-term statistical data, the yield of grain crops in the fields of specialized seed farms is always at least 2 times higher than the yield in conventional farms producing food and feed grain. In Russia in 2-3 times higher. Table 4 data allowed to calculate the required number of seeds for the Republic of Kazakhstan and the total number of seed farms (table. 5).

Table 5. The required number of seeds for farms in Kazakhstan by regions

\begin{tabular}{|c|c|c|c|c|c|}
\hline $\begin{array}{l}\text { Area } \\
\text { category }\end{array}$ & $\begin{array}{l}\text { The total } \\
\text { grain } \\
\text { harvest } \\
\text { mln. t. } \\
\sum \mathrm{W}_{3}\end{array}$ & $\begin{array}{l}\text { The total } \\
\text { amount of } \\
\text { grain, left after } \\
\text { processing } \\
0,85 \sum \mathrm{W}_{3} \\
\text { mln.t. }\end{array}$ & $\begin{array}{l}\begin{array}{l}\text { Required } \\
\text { number of } \\
\text { seeds for the } \\
\text { region } \mathrm{W}_{\text {пс }}, \\
\text { mln.t. }\end{array} \\
0,13 * 0,85 \mathrm{x} \\
\mathrm{W}_{5} \text {. }\end{array}$ & $\begin{array}{l}\text { The } \\
\text { required } \\
\text { number of } \\
\text { seed } \\
\text { farms in } \\
\text { region, } \\
\text { units }\end{array}$ & $\begin{array}{l}\text { Average } \\
\text { seeding rate } \\
\mathrm{kg} / \mathrm{ha}\end{array}$ \\
\hline $\mathrm{I}$ & 16,15 & 13,73 & 1,78 & 220 & 134 \\
\hline II & 3,26 & 2,77 & 0,36 & 128 & 97 \\
\hline III & 2,9 & 2,47 & 0,32 & 313 & 141 \\
\hline Total: & 22,31 & 19,0 & 2,47 & 616 & 125 \\
\hline
\end{tabular}

Thus, the total demand for seeds for Kazakhstan is 2.46 million tons, according to the categories of regions, respectively, $1.78 ; 0.36 ; 0.32$; million tons with an average seeding rate of $125 \mathrm{~kg}$ per hectare of grain area. To do this, the total number of seed farms should be 661, which exceeds their available number by 1.82 times.

This gave us the opportunity to develop recommendations for the necessary collection of grain and seeds in each region of Kazakhstan. At the same time, it is taken into account 
that $12-16 \%$ of impurities and defective grain are eliminated during the processing of the crop taken from the field.

Specialized seed farms in the amount of 661 units should have seed production at the level of the required control volumes of seeds (table.3) and the structure of the corresponding typical farms for each category in accordance with table 3 and 4.

The most typical combine harvesters for Kazakhstan are combines of Russian production: SK-5M "Niva", Yenisei -1200, Vector -410, Akros-530. The grain from the harvesters most often taken car GAZ-53 and ZIL-130 with a corresponding load capacity 4 and 5 .

Analysis of technical support of seed farms in Kazakhstan showed that the greatest need is in grain cleaning equipment including machines and equipment for seed preparation. One of the ways to improve the sowing qualities of seeds is the irradiation of seeds in a lowfrequency electromagnetic field $[8,9,10]$. Each seed farm should have a mobile or stationary plant for irradiating seeds before sowing in a low-frequency electromagnetic field. As a mobile unit can be any combine harvester, in the hopper of which are installed panels of low-quality radiator [8].

\section{Conclusion}

1. In general, in Kazakhstan there is a fairly stable grain production in all areas with a deviation from the average value of indicators within $2-6 \%$, which makes it possible in further calculations to focus on production indicators in 2018 as more updated.

2. Grain-producing regions of Kazakhstan on the scale of grain production per year can be classified into three categories: I-16,14 million tons: II-3,26 and III-2,9 million tons.

3.The first category includes Akmola, Kostanay and North Kazakhstan regions: the second - Almaty, Karaganda and Pavlodar regions; the third-Aktobe, West Kazakhstan, Turkestan, East Kazakhstan and Zhambyl regions with the corresponding sown areas under grain:11.182; $2.0 ; 1.84$ million hectares.

4. The following annual supplies of seeds from each category of regions are recommended: I-1,78; II-0,36; III-0,32 million tons with a total need of 2.46 million tons.

5. Recommended average areas of grain in one seed farm by their categories are: I-2,7 thousand hectares; II-1100 hectares; III-322 hectares.

6 . The total number of seed farms should be equal to 661, including the categories of regions: $220 ; 128 ; 313$ units.

\section{References}

1. System of measures to improve the seed system for 2017- 2021 (seed development map) (Astana: Ministry of agriculture farms of the Republic of Kazakhstan, 2018)

2. Statistical collection of ARKS: "Agriculture, forestry and fisheries" (Astana: Agency of the Republic of Kazakhstan on statistics, 2017)

3. O.P. Christin, M. Finance and statistics, pp. 136 (1981)

4. B.A. Dospekhov Technique of field experience (Moscow: Agropromizdat, 1985) $351 \mathrm{p}$.

5. V.I. Chernoivanov, A.A. Ezhevsky, V.F. Fedorenko. Global trend of a machinetechnological support of intelligent agriculture (FSBSI "Rosinformagrotech", 2012) $283 p$.

6. S. V. Pyanov. Large-scale production of grain (Stavropol, edited in AGRUS, 2014) $244 p$. 
7. E.V. Zhalnin. Methodological aspects of mechanization of production of grain in Russia (Moscow: Polygraph service, 2012) 368p.

8. L.S. Shibryaeva, Zh.S. Sadykov, E.V. Zhalnin. The impact of different types of cure for grain material SVM (Almaty- Moscow: Publishing house. Agrouniversity, 2015) $119 \mathrm{p}$.

9. Patent Republic of Kazakhstan №33082 " Device for irradiation of grain in the back of the vehicle." Bull. №35 from 17.09.2018. - Sadykov Zh. S., Izmailov A.Yu. etc.

10. Application for invention No. 2019/0038.1 "A device for processing of seed or grain by electromagnetic field of low-frequency radiation in the vehicle back with the process of distribution system" // RSE on PVC "National institute of intellectual property of " MU RK - Sadykov Zh., Espolov T., Alchimbayeva A., Zhalnin E. et al. 